\title{
Influence of ruminal degradable intake protein restriction on characteristics of digestion and growth performance of feedlot cattle during the late finishing phase
}

Dixie May ${ }^{1}$, Jose F Calderon ${ }^{1}$, Victor M Gonzalez , Martin Montano ${ }^{1}$, Alejandro Plascencia ${ }^{1}$, Jaime Salinas-Chavira ${ }^{2}$, Noemi Torrentera ${ }^{1}$ and Richard A Zinn ${ }^{3^{*}}$

\begin{abstract}
Two trials were conducted to evaluate the influence of supplemental urea withdrawal on characteristics of digestion (Trial 1) and growth performance (Trial 2) of feedlot cattle during the last 40 days on feed. Treatments consisted of a steam-flaked corn-based finishing diet supplemented with urea to provide urea fermentation potential (UFP) of 0, 0.6, and 1.2\%. In Trial 1, six Holstein steers $(160 \pm 10 \mathrm{~kg}$ ) with cannulas in the rumen and proximal duodenum were used in a replicated $3 \times 3$ Latin square experiment. Decreasing supplemental urea decreased (linear effect, $P \leq 0.05$ ) ruminal OM digestion. This effect was mediated by decreases (linear effect, $P \leq 0.05$ ) in ruminal digestibility of NDF and $N$. Passage of non-ammonia and microbial $N(M N)$ to the small intestine decreased (linear effect, $P=0.04$ ) with decreasing dietary urea level. Total tract digestion of OM (linear effect, $P=0.06$ ), NDF (linear effect, $P=0.07$ ), $\mathrm{N}$ (linear effect, $P=0.04$ ) and dietary DE (linear effect, $P=0.05$ ) decreased with decreasing urea level. Treatment effects on total tract starch digestion, although numerically small, likewise tended (linear effect, $P=0.11$ ) to decrease with decreasing urea level. Decreased fiber digestion accounted for $51 \%$ of the variation in $\mathrm{OM}$ digestion. Ruminal $\mathrm{pH}$ was not affected by treatments averaging 5.82. Decreasing urea level decreased (linear effect, $P \leq 0.05$ ) ruminal $\mathrm{N}-\mathrm{NH}$ and blood urea nitrogen. In Trial 2, 90 crossbred steers ( $468 \mathrm{~kg} \pm 8$ ), were used in a $40 \mathrm{~d}$ feeding trial (5 steers/pen, 6 pens/ treatment) to evaluate treatment effects on final-phase growth performance. Decreasing urea level did not affect DMI, but decreased (linear effect, $P \leq 0.03)$ ADG, gain efficiency, and dietary NE. It is concluded that in addition to effects on metabolizable amino acid flow to the small intestine, depriving cattle of otherwise ruminally degradable $\mathrm{N}(\mathrm{RDP})$ during the late finishing phase may negatively impact site and extent of digestion of OM, depressing ADG, gain efficiency, and dietary NE.
\end{abstract}

Keywords: Cattle, Degradable protein, Digestion, Growth performance

\section{Background}

Because of its low cost per unit of $\mathrm{N}$ compared with most sources of natural protein, urea is a primary source of supplemental $\mathrm{N}$ in conventional steam-flaked corn-based finishing diets for feedlot cattle [1]. In a review of nutrition consultant recommendations across 11 states in the USA, Vasconcelos and Galyean [2] observed that on average, flaked corn-based finishing diets contained $13.5 \% \mathrm{CP}$ with

\footnotetext{
*Correspondence: razinn@ucdavis.edu

${ }^{3}$ Department of Animal Science, University of California, Davis E. Holton Rd, El Centro, CA 92242, USA

Full list of author information is available at the end of the article
}

$1.2 \%$ of supplemental urea (approximately 64\% DIP). Although dietary formulation in this manner is expected to meet urea fermentation potential (UFP) for optimal microbial growth, it may exceed protein requirements for cattle growth, particularly during the late finishing phase. Preston [3] proposed the feasibility of restricting protein supplementation during the late finishing phase as a means of minimizing $\mathrm{N}$ excess and associated environmental impact $[1,4]$ without detrimentally affecting cattle performance. However, the impact of this practice on digestive function and cattle growth-performance has received limited research attention. The aim of this study was to 
evaluate the influence of UFP for optimal microbial growth on characteristics of digestion and growth performance of feedlot cattle during the late finishing phase.

\section{Methods}

All procedures involving animal care and management were in accordance with and approved by the University of California, Davis, Animal Use and Care Committee.

\section{Trial 1}

Six Holstein steers $(160 \pm 10 \mathrm{~kg})$ with cannulas in the rumen and proximal duodenum [5] were used in $3 \times 3$ replicated Latin square experiment. Burroughs et al. [6] proposed that amount of degradable intake protein (DIP) necessary to optimize microbial growth was equivalent to the net microbial protein synthesis. Accordingly, the urea fermentation potential of the diet (percentage of additional urea that may be added to the diet in order to optimize microbial growth) would be equivalent to: (0.104TDN- DPI)/ 2.8, where TDN is expressed as a percentage, and DPI is expressed as the percentage of RDP in the basal diet before urea supplementation. Accordingly, treatments consisted of a steam flaked corn-based finishing diet adjusted for restriction of rumen DIP to provide urea fermentation potentials of 0 (UFP-0), 0.6 (UFP-0.6) and 1.2\% (UFP-1.2). Composition of experimental diets is shown in Table 1. Chromic oxide $(0.40 \%$, DM basis) was included in diets as a digesta marker. Dry matter intake was restricted to 4.0 $\mathrm{kg} / \mathrm{d}(2.2 \%$ of BW daily), and feed was offered in equal portions at 0800 and 2000 daily. The three experimental periods consisted of a 10-d diet adjustment period followed by a 4-d collection period. During the collection period duodenal and fecal samples were taken from all steers, twice daily as follows: d 1, 1050 and 1450; d 2, 0900 and 1500; d 3, 0730 and 1330, and d 4, 0600 and 1200. Individual samples consisted of approximately $750 \mathrm{~mL}$ of duodenal chyme and $200 \mathrm{~g}$ (wet basis) of fecal material. Samples from each steer and within each collection period were composited for analysis. During the final day of each collection period, $4 \mathrm{~h}$ after feeding, ruminal and blood samples were collected from each steer via ruminal cannula and caudal venous respectively. Ruminal fluid $\mathrm{pH}$ was determined by inserting a $\mathrm{pH}$ electrode into the freshly collected samples. The ruminal fluid sample was divided into two parts: $40 \mathrm{~mL}$ was measured into a plastic bag, placed in an ice bath, and carried to a laboratory for determination of $\mathrm{N}-\mathrm{NH}$ in fresh ruminal fluid [7]. The remainder was strained through four layers of cheesecloth. Ten $\mathrm{mL}$ of freshly prepared $25 \%$ (wt/vol) metaphosphoric acid was added to $40 \mathrm{~mL}$ of strained ruminal fluid, $10 \mathrm{~mL}$ were then centrifuged $(17,000 \times g$ for $10 \mathrm{~min})$, and supernatant fluid was stored at $-20^{\circ} \mathrm{C}$ for VFA analysis. Upon completion of the trial, ruminal fluid was obtained via the ruminal cannula from all steers and composited for
Table 1 Diet composition of experiment 1 and $2^{1}$

\begin{tabular}{|c|c|c|c|}
\hline \multirow[b]{2}{*}{ Item } & \multicolumn{3}{|c|}{ Urea fermentation potential } \\
\hline & 0 & 0.6 & 1.2 \\
\hline \multicolumn{4}{|c|}{ Ingredient (g/kg of DM) } \\
\hline Steam flaked corn & 797.5 & 803.0 & 809.0 \\
\hline Sudangrass hay & 50.0 & 50.0 & 50.0 \\
\hline Alfalfa hay & 50.0 & 50.0 & 50.0 \\
\hline Urea & 12.5 & 7.0 & 1.0 \\
\hline Cane molasses & 50.0 & 50.0 & 50.0 \\
\hline Yellow grease & 20.0 & 20.0 & 20.0 \\
\hline Limestone & 14.0 & 14.0 & 14.0 \\
\hline Trace mineral salt ${ }^{2}$ & 4.0 & 4.0 & 4.0 \\
\hline Magnesium oxide & 2.0 & 2.0 & 2.0 \\
\hline Monensin ${ }^{3}$ & 0.022 & 0.022 & 0.022 \\
\hline \multicolumn{4}{|c|}{ Nutrient composition (DM basis) ${ }^{4}$} \\
\hline $\mathrm{NE}_{\mathrm{m}}(\mathrm{Mcal} / \mathrm{kg})$ & 2.23 & 2.24 & 2.25 \\
\hline $\mathrm{NE}_{\mathrm{g}}(\mathrm{Mcal} / \mathrm{kg})$ & 1.56 & 1.56 & 1.58 \\
\hline DE (Mcal/kg) & 3.86 & 3.86 & 3.89 \\
\hline $\mathrm{CP}(\mathrm{g} / \mathrm{kg})$ & 130.0 & 115.0 & 99.1 \\
\hline $\operatorname{RDP}(\mathrm{g} / \mathrm{kg}$ of $\mathrm{CP})$ & 648 & 600 & 530 \\
\hline NDF $(g / k g)$ & 125.0 & 125.0 & 125.0 \\
\hline Calcium (g/kg) & 6.6 & 6.6 & 6.6 \\
\hline Phosphorus (g/kg) & 2.8 & 2.8 & 2.8 \\
\hline
\end{tabular}

${ }^{1}$ Chromic oxide $(0.40 \%)$ was added in substitution of corn grain as a digesta marker in Trial 1. RDIP, rumen degradable intake protein. UFP, estimated urea fermentation potential.

${ }^{2}$ Trace mineral salt contained: CoSO4, 0.068\%; CuSO4, 1.04\%; FeSO4, 3.57\%; $\mathrm{ZnO}, 1.24 \%$; MnSO4, 1.07\%; Kl, 0.052\%; and NaCl, 92.96\%.

${ }^{3}$ Rumensin80 (Elanco Animal Health, Greenfield, IN).

${ }^{4}$ Based on tabular values for individual feed ingredients (NRC, [17]).

microbial isolation via differential centrifugation [8]. The microbial isolates were prepared for analysis by oven drying at $70^{\circ} \mathrm{C}$ and then grinding with mortar and pestle. Feed, duodenal, and fecal samples were prepared for analysis by oven drying at $70^{\circ} \mathrm{C}$ and then grinding in a laboratory mill. Samples were then oven dried at $105^{\circ} \mathrm{C}$ until no further weight loss occurred and stored in tightly sealed glass jars. Samples were subjected to all or part of the following analysis: DM (oven-drying at $105^{\circ} \mathrm{C}$ until no further weight loss), ash, N-NH, Kjeldahl $\mathrm{N}$ [9], NDF-adjusted for insoluble ash [10], purines [11], starch [12] and VFA concentrations of ruminal fluid (gas chromatography; [13]), GE (adiabatic bomb calorimetry), and chromic oxide [14]. Duodenal flow and fecal excretion of DM were calculated based on marker ratio, using chromic oxide. Microbial organic matter (MOM) and microbial $\mathrm{N}(\mathrm{MN})$ leaving the abomasum were calculated using purines as a microbial marker [11]. Organic matter fermented in the rumen was considered equal to $\mathrm{OM}$ intake minus the difference between the amount of total OM reaching the duodenum and MOM reaching the duodenum. Feed N 
escape to the small intestine was considered equal to total $\mathrm{N}$ leaving the abomasum minus $\mathrm{N}-\mathrm{NH}$, microbial, and endogenous $\mathrm{N}\left(0.195 \mathrm{~g} / \mathrm{kg} \mathrm{W}^{0.75} ;\right.$ [15]). Methane production ( $\mathrm{mol} / \mathrm{mol}$ of glucose equivalent fermented) was estimated based on the theoretical fermentation balance for observed molar distribution of VFA [16]. Whole blood samples were centrifuged and the plasma frozen for BUN analysis. The blood samples collected were centrifuged and the plasma analyzed for Blood Urea Nitrogen (BUN) by slide method using Vitros Bun/Urea DT60 II (Ortho Clinical Diagnostics, Inc., Rochester, NY), and ruminal N-NH [7]. The effects of the urea level on characteristics of digestion in cattle were analyzed as a $3 \times 3$ replicated Latin square design using the MIXED procedure (SAS Inst. Inc., Cary, NC). The fixed effect consisted of treatment, and random effects consisted of steer and period. The statistical model for the trial was as follows:

$$
Y_{i j k}=\mu+R_{l}+S_{i(l)}+P_{j(l)}+T_{k}+E_{i j k}
$$

where: $Y_{i j k}$ is the response variable, $\mu$ is the common experimental effect, $R_{l}$ is the replicated effect, $S_{i}$ is the steer effect within replicate, $P_{j}$ is the period effect within replicate, $T_{k}$ is the treatment effect and $E_{i j k}$ is the residual error. Treatment effects were tested using the following contrasts: 1) linear effect of the urea level, and 2) quadratic effect of the urea level, which were determined according to SAS (SAS Inst., Inc., Cary, NC; Version 9.1).

\section{Trial 2}

Ninety crossbred steers with an average initial weight of $468 \pm 8 \mathrm{~kg}$ were used in a $40 \mathrm{~d}$ finishing trial to evaluate the treatment effects on growth performance. Steers had a purchase weight of $214 \pm 14 \mathrm{~kg}$ and had been on feed $197 \mathrm{~d}$ before initiation of the study. Steers had been implanted with Synovex-S (Zoetis, Florham Park, NJ) upon arrival into the feedlot and with Revalor-S (Merck Animal Health, Summit, NJ) on d 98. Ten d prior to initiation of the study steers were weighed, reimplanted with Revalor-S, blocked by weight and randomly allotted within weight groupings to 18 pens (5 steers/pen). Pens were $43 \mathrm{~m}^{2}$, with $22 \mathrm{~m}^{2}$ of overhead shade, automatic waterers, and $2.4 \mathrm{~m}$ long fence-line feed bunks. Dietary treatments were the same as those used in Experiment 1. All steers received the UFP-0 diet for $10 \mathrm{~d}$ prior to initiation of the trial. Diets were prepared at weekly intervals and stored in plywood boxes located in front of each pen. Steers were allowed free access to dietary treatments. Fresh feed was provided twice daily. Individual steers were weighed upon initiation and completion of the trial. In the calculation of steer performance live weights were reduce $4 \%$ to adjust for digestive tract fill. Estimates of steer performance were based on pen means. Net energy values for each diet were calculated from estimates of energy gain (EG, Mcal/d) based on growth-performance; $\mathrm{EG}=0.0557 \mathrm{BW}^{0.75}\left(\mathrm{ADG}^{1.097}\right)$, where $\mathrm{EG}$ is the daily energy deposited (Mcal/d), BW is the mean shrunk body weight (full weight $\times 0.96$ ) and maintenance energy expended (EM, Mcal/d); $\mathrm{EM}=0.077 \mathrm{BW}^{0.75}$ [18]. Dietary $\mathrm{NEg}$ was derived from $\mathrm{NE}_{\mathrm{m}}$ by the equation: $\mathrm{NE}_{\mathrm{g}}=0.877$ $\mathrm{NE}_{\mathrm{m}}-0.41$ [19]. Dry matter intake is related to energy requirements and dietary $\mathrm{NE}_{\mathrm{m}}$ according to the equation: $\mathrm{DMI}=\mathrm{EG} / \mathrm{NE}_{\mathrm{g}}$ ), and can be resolved for estimation of dietary NE by means of the quadratic formula: $x=\frac{-b \pm \sqrt{b^{2}-4 a c}}{2 a}$, where $\mathrm{x}=\mathrm{NE}_{\mathrm{m}}, \mathrm{a}=-0.877 \mathrm{DMI}, \mathrm{b}=$ $0.877 \mathrm{EM}^{2 a}+0.41 \mathrm{DMI}+\mathrm{EG}$, and c = -0.41 EM [19].

All steers were harvested on the same day. Each carcass was weighed at time of slaughter to determine dressing percentage [20]. Performance (gain, gain efficiency, and dietary energetics) and carcass data were analyzed as a randomized complete block design; the experimental unit was the pen. The MIXED procedure of SAS [21] was used to analyze the variables. The fixed effect consisted of treatment, and pen was the random component. Treatments effects were tested using the following contrasts: 1) linear effect of the urea level, and 2) quadratic effect of the urea level, which were determined according to SAS [21].

\section{Results and discussion}

The influence of dietary treatments on ruminal and total tract digestion is shown in Table 2. Decreasing supplemental urea decreased (linear effect, $P \leq 0.05$ ) ruminal $\mathrm{OM}$ digestion. This effect was mediated by decreases in ruminal digestibility of NDF (linear effect, $P=0.05$ ), starch (linear effect, $P=0.09$ ) and $\mathrm{N}$ (linear effect, $P=0.04$ ). Likewise, Zinn et al. [22] observed decreased ruminal digestion of OM, NDF and starch in response to decreasing urea supplementation of a steam-flaked corn-based finishing diet fed to feedlot steers [22].

Passage of non-ammonia $\mathrm{N}$ to the small intestine decreased (linear effect, $P=0.04$ ) with decreasing dietary urea level. This effect was due to decreased (linear effect, $P=0.04) \mathrm{MN}$ synthesis. Taking into consideration energy intake alone, predicted flow of $\mathrm{MN}$ to the small intestine was 48g/d ([17], Level 1). Accordingly, with decreasing urea level, the observed flow of MN to the small intestine was 85,73 , and $65 \%$ of predicted flow for UFP-0, UFP-0.6, and UFP-1.2, respectively. This decline in net synthesis is consistent with [19] who observed that MN flow to the small intestine declines with decreasing DIP below $100 \mathrm{~g} / \mathrm{kg}$ of total tract digestible OM. For the present study, DIP averaged 95, 81, and $61 \mathrm{~g} / \mathrm{kg}$ total tract digestible OM for UFP-0, UFP-0.6, and UFP-1.2, respectively. Thus, it is apparent that as DIP intake drops below $95 \mathrm{~g} / \mathrm{kg}$ digestible OM there is not sufficient compensation in ruminal $\mathrm{N}$ recycling to maintain microbial growth, and as microbial growth declines, likewise, ruminal OM digestion declines. 
Table 2 Influence of dietary treatments on characteristics of digestion

\begin{tabular}{|c|c|c|c|c|c|c|}
\hline \multirow[b]{2}{*}{ Item } & \multicolumn{3}{|c|}{ Urea fermentation potential } & \multicolumn{2}{|c|}{$P$ - value } & \multirow[b]{2}{*}{ SEM } \\
\hline & 0 & 0.6 & 1.2 & Linear & Quadratic & \\
\hline Steer replications & 6 & 6 & 6 & & & \\
\hline \multicolumn{7}{|l|}{ Intake (g/d) } \\
\hline DM & 3556 & 3553 & 3551 & & & \\
\hline OM & 3343 & 3359 & 3378 & & & \\
\hline NDF & 453 & 455 & 457 & & & \\
\hline N & 66.2 & 57.6 & 48.2 & & & \\
\hline Starch & 1907 & 1919 & 1932 & & & \\
\hline GE (Mcal/d) & 15.2 & 15.2 & 15.3 & & & \\
\hline \multicolumn{7}{|c|}{ Flow to the duodenum $(\mathrm{g} / \mathrm{d})$} \\
\hline OM & 1655 & 1749 & 1894 & 0.05 & 0.76 & 83.0 \\
\hline NDF & 338 & 370 & 456 & 0.05 & 0.55 & 42.0 \\
\hline Starch & 385 & 441 & 533 & 0.08 & 0.77 & 61.0 \\
\hline Total N & 76.4 & 68.8 & 64.4 & 0.04 & 0.70 & 4.0 \\
\hline Microbial N & 40.6 & 34.7 & 31.4 & 0.04 & 0.69 & 3.0 \\
\hline $\mathrm{NH}-\mathrm{N}$ & 2.30 & 2.04 & 1.58 & 0.06 & 0.72 & 0.3 \\
\hline Non-ammonia N & 74.1 & 66.7 & 62.9 & 0.04 & 0.66 & 3.8 \\
\hline Feed N & 24.7 & 23.2 & 22.7 & 0.20 & 0.71 & 0.9 \\
\hline \multicolumn{7}{|c|}{ Ruminal digestibility, \% } \\
\hline $\mathrm{OM}$ & 62.6 & 58.3 & 53.23 & 0.04 & 0.91 & 0.3 \\
\hline NDF & 25.3 & 18.6 & 0.30 & 0.05 & 0.54 & 0.9 \\
\hline Starch & 79.8 & 77.0 & 72.4 & 0.09 & 0.78 & 0.3 \\
\hline Feed N & 62.6 & 59.7 & 52.9 & 0.04 & 0.64 & 0.5 \\
\hline Microbial efficiency ${ }^{1}$ & 19.4 & 17.8 & 17.5 & 0.06 & 0.40 & 0.7 \\
\hline$N$ efficiency $^{2}$ & 1.12 & 1.16 & 1.30 & 0.05 & 0.44 & 0.07 \\
\hline \multicolumn{7}{|l|}{ Fecal excretion (g/d) } \\
\hline OM & 624 & 705 & 756 & 0.06 & 0.77 & 48.0 \\
\hline NDF & 282 & 319 & 348 & 0.06 & 0.87 & 25.0 \\
\hline Starch & 35.9 & 49.0 & 56.6 & 0.10 & 0.78 & 9.4 \\
\hline Total N & 20.9 & 22.2 & 21.8 & 0.48 & 0.44 & 1.0 \\
\hline GE (Mcal/d) & 3.28 & 3.66 & 3.90 & 0.05 & 0.75 & 0.84 \\
\hline \multicolumn{7}{|c|}{ Postruminal digestibility (\% of flow to duodenum) } \\
\hline OM & 62.2 & 59.7 & 60.0 & 0.37 & 0.49 & 1.9 \\
\hline NDF & 15.3 & 11.2 & 22.8 & 0.41 & 0.33 & 7.3 \\
\hline Starch & 90.5 & 89.1 & 89.3 & 0.60 & 0.69 & 1.9 \\
\hline Total N & 72.6 & 67.6 & 66.2 & 0.08 & 0.53 & 2.7 \\
\hline \multicolumn{7}{|c|}{ Total tract digestibility (\% of intake) } \\
\hline OM & 81.3 & 79.0 & 77.6 & 0.06 & 0.75 & 1.4 \\
\hline NDF & 37.8 & 29.8 & 23.9 & 0.07 & 0.85 & 5.3 \\
\hline Starch & 98.1 & 97.4 & 97.1 & 0.11 & 0.77 & 0.5 \\
\hline Total N & 68.5 & 61.5 & 54.9 & 0.04 & 0.97 & 4.5 \\
\hline$D E, \%$ & 78.5 & 76.0 & 74.5 & 0.05 & 0.74 & 1.4 \\
\hline DE, Mcal/kg & 3.36 & 3.26 & 3.20 & 0.05 & 0.73 & 0.06 \\
\hline
\end{tabular}

${ }^{1}$ Microbial N, g/kg OM fermented.

${ }^{2}$ Nonammonia $\mathrm{N}$ flow to the small intestine as a fraction of $\mathrm{N}$ intake. 
There were no treatment effects $(P=0.20)$ on passage of feed $\mathrm{N}$ to the small intestine. Notwithstanding decreased non-ammonia $\mathrm{N}$ flow to the small intestine with decreasing urea level, ruminal $\mathrm{N}$ efficiency (non-ammonia $\mathrm{N}$ flow to the small intestine as a fraction of $\mathrm{N}$ intake) increased (linear $P<0.05)$, reflecting increased contribution of recycled $\mathrm{N}$ into microbial protein synthesis, consistent with the observation that ruminal $\mathrm{N}$ flux increases inversely with dietary $\mathrm{N}$ concentration [23]. Observed DIP (Table 2) averaged 103\% of expected based on tabular values ([17]; Table 1) for the three dietary treatments.

Total tract digestion of OM (linear effect, $P=0.06$ ), NDF (linear effect, $P=0.07$ ), $\mathrm{N}$ (linear effect, $P=0.04$ ) and dietary DE (linear effect, $P=0.05$ ) decreased with decreasing urea level. Treatment effects on total tract starch digestion, although numerically small, likewise tended (linear effect, $P=0.11$ ) to decrease with decreasing urea level. Decreased fiber digestion accounted for $51 \%$ of the variation in $\mathrm{OM}$ digestion. In a previous study involving steam-flaked corn-based finishing diets in which urea was the sole source of supplemental $\mathrm{N}$ [22], increasing urea level from 1.0 to $1.6 \%$ of the steam-flaked corn in the diet (an upper level similar to that of the present study; Table 1) likewise enhanced total tract OM and fiber digestion. In contrast Zinn and Shen [19] observed removal of urea from a steam-flaked corn-based growing-finishing diet markedly depressed ruminal OM digestion and flow of $\mathrm{MN}$ to the small intestine but did not affect total tract $\mathrm{OM}$ digestion. Treatment effects on apparent $\mathrm{N}$ digestion were largely a function of the $\mathrm{N}$ content of the diet brought about by changes in dietary urea level [24].

Treatment effects on ruminal pH, VFA molar proportions, and BUN are showen in Table 3. Ruminal pH (measured 4-h postprandium) was not affected $(P=0.51)$ by treatments, averaging 5.82. Upon hydrolysis, dietary urea can have an appreciable alkalizing effect on ruminal $\mathrm{pH}$ during the first hour post-feeding [25]. However by $4 \mathrm{~h}$ postprandium, the effect of urea supplementation of corn-based diets on ruminal $\mathrm{pH}$ has been negligible [22,26,27].

Decreasing urea level decreased (linear effect, $P<0.01$ ) ruminal N-NH. The N-NH concentration has been reported to increase immediately after feeding for 2 to $3 \mathrm{~h}$ $[28,29]$. Satter and Roffler [30] observed a close relationship $\left(\mathrm{R}^{2}=0.92\right)$ between the level of dietary $\mathrm{CP}$ and ruminal $\mathrm{N}-\mathrm{NH}$ concentration at given dietary TDN. Likewise, in the present study dietary CP explained $88 \%$ of the variation ruminal N-NH concentration. Blood urea nitrogen (BUN) concentration $4 \mathrm{~h}$ postprandium also decreased (linear effect, $P<0.01$ ) with decreasing urea supplementation. Blood urea nitrogen is also closely associated dietary $\mathrm{CP}$ and ruminal N-NH concentrations [31,32]. Consistent with Zinn et al. [22], decreasing urea level increased ruminal acetate:propionate molar ratio (linear effect, $P=0.05)$, and estimated methane production $(\mathrm{mol} / \mathrm{mol}$ glucose equivalent fermented; linear effect, $P=0.04$ ).

Treatment effects on growth performance of feedlot steers are shown in Table 4. Decreasing urea level did not affect DMI $(P=0.32)$, but decreased ADG (linear effect, $P<0.01$ ), gain efficiency (linear effect, $P<0.01$ ), and dietary NE (linear effect, $P=0.03$ ). Few research has evaluated the influence of marked RDP restriction on growth-performance and dietary NE in feedlot cattle fed steam-flaked corn-based finishing diets. As with the present study, Zinn et al. [22] observed a linear increase in urea resulted in a linear increase in ADG, gain efficiency and dietary NE linearly increased. The UFP of the basal

Table 3 Treatment effects on ruminal pH, VFA molar proportions and BUN

\begin{tabular}{|c|c|c|c|c|c|c|}
\hline \multirow[b]{2}{*}{ Item } & \multicolumn{3}{|c|}{ Urea fermentation potential } & \multicolumn{2}{|c|}{$P$ - value } & \multirow[b]{2}{*}{ SEM } \\
\hline & 0 & 0.6 & 1.2 & Linear & Quadratic & \\
\hline Ruminal pH & 5.75 & 5.86 & 5.84 & 0.51 & 0.59 & 0.10 \\
\hline Ruminal N-NH (mg/dL) & 5.37 & 4.69 & 3.89 & 0.05 & 0.91 & 0.56 \\
\hline Total VFA (mM) & 95.9 & 105 & 94.2 & 0.83 & 0.21 & 5.4 \\
\hline \multicolumn{7}{|c|}{ Ruminal VFA (mol/100 mol) } \\
\hline Acetate & 46.8 & 49.2 & 57.5 & 0.08 & 0.54 & 4.6 \\
\hline Propionate & 36.1 & 30.1 & 20.3 & 0.04 & 0.74 & 5.7 \\
\hline Isobutyrate & 1.19 & 1.17 & 0.89 & 0.30 & 0.60 & 0.23 \\
\hline Butyrate & 12.0 & 15.1 & 17.7 & 0.17 & 0.93 & 3.1 \\
\hline Isovalerate & 1.53 & 1.77 & 0.83 & 0.19 & 0.20 & 0.41 \\
\hline Valerate & 2.36 & 2.63 & 2.83 & 0.42 & 0.95 & 0.48 \\
\hline Acetate:propionate & 1.34 & 1.85 & 2.94 & 0.05 & 0.63 & 0.59 \\
\hline Methane ${ }^{1}$ & 0.35 & 0.44 & 0.60 & 0.04 & 0.70 & 0.09 \\
\hline BUN (mg/dL) & 4.43 & 2.80 & 1.45 & $<0.01$ & 0.53 & 0.25 \\
\hline
\end{tabular}

${ }^{1}$ Methane production ( $\mathrm{mol} / \mathrm{mol}$ of glucose equivalent fermented) was estimated based on the theoretical fermentation balance for observed molar distribution of VFA [16]. 
Table 4 Treatment effects on growth performance and carcass weight of feedlot steers

\begin{tabular}{|c|c|c|c|c|c|c|}
\hline \multirow[b]{2}{*}{ Item } & \multicolumn{3}{|c|}{ Urea fermentation potential } & \multicolumn{2}{|c|}{$P$-value } & \multirow[b]{2}{*}{ SEM } \\
\hline & 0 & 0.6 & 1.2 & Linear & Quadratic & \\
\hline Days on test & 40 & 40 & 40 & & & \\
\hline Pen replicates & 5 & 5 & 5 & & & \\
\hline \multicolumn{7}{|c|}{ Live weight $(\mathrm{kg})^{1}$} \\
\hline Initial & 469 & 465 & 470 & 0.83 & 0.28 & 3.22 \\
\hline Final & 510 & 502 & 501 & 0.17 & 0.54 & 4.40 \\
\hline DMl (kg/d) & 7.32 & 6.99 & 6.94 & 0.32 & 0.67 & 0.26 \\
\hline ADG (kg/d) & 1.04 & 0.93 & 0.78 & $<0.01$ & 0.71 & 0.06 \\
\hline G:F & 0.142 & 0.134 & 0.112 & $<0.01$ & 0.32 & 0.005 \\
\hline \multicolumn{7}{|c|}{ Diet NE (Mcal/kg) } \\
\hline Maintenance & 2.37 & 2.33 & 2.18 & 0.03 & 0.37 & 0.21 \\
\hline Gain & 1.67 & 1.64 & 1.50 & 0.03 & 0.37 & 0.21 \\
\hline \multicolumn{7}{|c|}{ Observed/expected NE } \\
\hline Maintenance & 1.07 & 1.05 & 0.98 & 0.03 & 0.37 & 0.02 \\
\hline Gain & 1.09 & 1.07 & 0.98 & 0.03 & 0.37 & 0.03 \\
\hline HCW (kg) & 336 & 331 & 330 & 0.16 & 0.67 & 3.02 \\
\hline Dressing (\%) & 65.9 & 66.0 & 65.8 & 0.80 & 0.67 & 0.23 \\
\hline
\end{tabular}

${ }^{1}$ Initial and final weights were reduced $4 \%$ to adjust for digestive tract fill.

unsupplemented diet in that trial was $1.36 \%$, indicating that cattle performance may be enhanced when level of urea supplementation exceeded that necessary for maximal ruminal microbial protein synthesis. As with steam-flaked corn, urea supplementation of dry rolled corn-based finishing diets to meet the UFP also enhanced ADG and gain efficiency [26,33].

The decrease in dietary NE due to restriction of rumen degradable intake protein observed in the growth performance trial (Table 4) is consistent with the decrease in dietary DE observed in the metabolism trial (Table 2). However, why cattle didn't simply compensate for this difference in NE by increasing energy intake to maintain their growth potential is puzzling. A comparison of requirements and estimated supply of metabolizable protein and the amino acids methionine and lysine for the various dietary treatments is given in Table 5. As per NRC [17], metabolizable protein supply was estimated as $80 \%$ of undegraded intake crude protein plus microbial crude protein entering small intestine in Trial 1 (Table 2), adjusted for level of intake of steers in Trial 2 (Table 4). Metabolizable amino acid supply was based on diet composition (Table 1) and corresponding tabular amino acid composition of RUP for individual feed ingredients and average amino acid composition of ruminal bacteria [17]. Metabolizable protein and amino acid requirements were based on average body weight and daily weight gain (Trial 2; NRC, [17], Level 1). As expected, estimated metabolizable protein and amino acid supply decreased with increasing UFP. Across treatments, estimated metabolizable protein supply exceeded requirements by an average of $11 \%$. Nevertheless, metabolizable protein supply for UFP-0.6 and UFP- 1.2 were less ( 2 and $8 \%$, respectively) than the estimated requirement to achieve daily weight gain observed with UFP-0 treatment. Particularly notable is the very close association between metabolizable methionine and lysine and requirements versus supply, indicative that daily weight gain may have been closely

Table 5 Treatment effects on metabolizable protein and amino acid supply ${ }^{1}$ versus requirements ${ }^{2}$

\begin{tabular}{lccc}
\hline & \multicolumn{2}{c}{ Urea fermentation potential } \\
\cline { 2 - 4 } Item & $\mathbf{0}$ & $\mathbf{0 . 6}$ & $\mathbf{1 . 2}$ \\
\hline Metabolizable protein, g/d & 688 & 600 & 565 \\
Supply & 613 & 574 & 493 \\
Requirement & & & \\
Metabolizable methionine, g/d & 12.4 & 10.6 & 9.9 \\
Supply & 12.3 & 11.5 & 9.9 \\
Requirement & & & 30.1 \\
Metabolizable lysine, g/d & 39.2 & 32.9 & 31.5 \\
Supply & 39.3 & 36.7 & \\
Requirement & & & \\
\hline M & & & \\
\end{tabular}

${ }^{1}$ Metabolizable protein supply estimated as $80 \%$ undegraded intake crude protein and microbial crude protein entering small intestine (Trial 1), adjusted for level of intake. Metabolizable amino acid supply based on diet composition and corresponding tabular amino acid composition of undegradable intake protein for individual feed ingredients and average amino acid composition of ruminal bacteria (NRC, [17]).

${ }^{2}$ Metabolizable protein and amino acid requirements based on average body weight and daily weight gain (Trial 2; NRC, [17], Level 1). 
mediated by supply of these two amino acids. As corn (the major contributor of protein to the basal diet) is a particularly poor source of lysine, and methionine, the diminution of microbial protein synthesis brought about by restriction in RDP, was sufficient to restrict growth.

\section{Conclusion}

It is concluded that in addition to effects on net protein flow to the small intestine, depriving cattle of otherwise RDP during the late finishing phase may negatively impact site and extent of OM digestion, depressing ADG, gain efficiency, and dietary NE.

\section{Competing interests}

The authors declare that they have no competing interests.

\section{Authors' contribution}

DM: PhD student, carried out growth performance and digestion trials, participated on laboratory analyses and manuscript preparation. JFC: Monitoring the growth performance trial. VGV: Carried out the digestion trial, participated on surgery and welfare of cattle. MM: Carried out the digestion trial, participated on samples procedures and manuscript preparation. APJ: Assisted in manuscript preparation. JS: Assisted in manuscript preparation. NT: Carried out the growth performance trial, participated on carcass evaluation and assisted in manuscript preparation. RZ: Experimental design, data analysis, and manuscript preparation. All authors read and approved the final manuscript.

\section{Author details}

'Instituto de Investigaciones en Ciencias Veterinarias, UABC, Mexicali, Baja California 21100, México. ${ }^{2}$ Facultad de Medicina Veterinaria y Zootecnia, UAT, Cd. Victoria, Tamaulipas 87000, México. ${ }^{3}$ Department of Animal Science, University of California, Davis E. Holton Rd, El Centro, CA 92242, USA.

Received: 29 April 2014 Accepted: 16 July 2014

Published: 13 August 2014

\section{References}

1. Vasconcelos JT, Cole NA, McBride KW, Gueye A, Galyean ML, Richardson CR, Greene LW: Effects of dietary crude protein and supplemental urea levels on nitrogen and phosphorus utilization by feedlot cattle. J Anim Sci 2009, 87:1174-1183

2. Vasconcelos JT, Galyean ML: Nutritional recommendations of feedlot consulting nutritionists: The 2007 Texas Tech University survey. J Anim SCi 2007, 85:2772-2781

3. Preston RL: Empirical value of the crude protein systems for feedlot cattle. In Protein Requirements for Cattle: Symposium. Edited by Owens FN. Stillwater, OK: Oklahoma Experimental Station MP-109, Oklahoma State University; 1982:201-217.

4. Hristov AN, Hanigan M, Cole A, Todd R, McAllister TA, Ndegwaand PM, Rotz A: Review: Ammonia emissions from dairy farms and beef feedlots. Can J Anim Sci 2011, 91:1-35.

5. Zinn RA, Plascencia A: Interaction of whole cottonseed and supplemental fat on digestive function in cattle. J Anim Sci 1993, 71:11-17.

6. Burroughs W, Nelson DK, Mertens DR: Protein physiology and its application in the lactating cow: The metabolizable protein feeding standard. J Anim Sci 1975, 41:933-944.

7. Fawcett JK, Scott JE: A rapid and precise method for the determination of urea. J Clin Pathol 1960, 13:156-159.

8. Bergen WG, Purser DB, Cline JH: Effect of ration on the nutritive quality of rumen microbial protein. J Anim Sci 1968, 27:1497-1501.

9. Association Official Analytical Chemists (AOAC): Official methods of analysis. 17th edition. Gaithersburg, MD: Association Official Analytical Chemists; 2000

10. Van Soest PJ, Robertson JB, Lewis BA: Methods for dietary fiber, neutra detergent fiber, and nonstarch polysaccharides in relation to animal nutrition. J Dairy Sci 1991, 74:3583-3597.
11. Zinn RA, Owens FN: A rapid procedure for purine measurement and its use for estimating net ruminal protein synthesis. Can J Anim Sci 1986, 66:157-166.

12. Zinn RA: Influence of steaming time on site digestion of flaked corn in steers. J Anim Sci 1990, 68:776-781.

13. Zinn RA: Comparative feeding value of supplemental fat in finishing diets for feedlot steers supplemented with and without monensin. J Anim Sci 1988, 66:213-227.

14. Hill FN, Anderson DL: Comparison of metabolizable energy and productive determinations with growing chicks. J Nutr 1958, 64:587-603.

15. Ørskov ER, MacLeod NA, Kyle DJ: Flow of nitrogen from the rumen and abomasum in cattle and sheep given protein-free nutrients by intragrastric infusion. Br J Nutr 1986, 56:241-248.

16. Wolin MJ: A theorical rumen fermentation balance. J Dairy Sci 1960, 43:1452-1459

17. National Research Council (NRC): Nutrient Requirements of Beef Cattle. 7th edition. Washington, DC: National Academy of Press; 1996.

18. National Research Council (NRC): Nutrient Requirements of Beef Cattle. 6th edition. Washington, DC: National Academy Press; 1984.

19. Zinn RA, Shen Y: An evaluation of ruminally degradable intake protein and metabolizable amino acid requirements of feedlot calves. J Anim Sci 1998, 76:1280-1289.

20. United States Department of Agriculture (USDA): United States Standards for Grading of Carcass Beef. Washington, DC: Agricultural Marketing Service, United States Department of Agriculture; 1997.

21. Statistical Analysis System (SAS): SAS/STAT User's Guide: Version 9.1. Cary, North Caroline: SAS Institute Inc: 2004.

22. Zinn RA, Borquez JL, Plascencia A: Influence of levels of supplemental urea on characteristics of digestion and growth performance of feedlot steers fed a fat-supplemented high-energy diets. Prof Anim Sci 1994, 10:5-10.

23. Muscher AS, Schroder B, Breves G, Huber K: Dietary nitrogen reduction enhances urea transport across goat rumen epithelium. J Anim Sci 2010 88:3390-3398.

24. Holter JA, Reid JT: Relationship between the concentrations of crude protein and apparently digestible protein in forages. J Anim Sci 1959, 18:1339-1349.

25. Zinn RA, Barrajas R, Montaño M, Ware RA: Influence of dietary urea level on digestive function and growth performance of cattle fed steamflaked barley- based finishing diets. J Anim Sci 2003, 81:2383-2389.

26. Milton $C T$, Brandt RT Jr, Titgemeyer EC: Urea in dry rolled corn diets: Finishing steers performance, nutrient digestion and microbial protein production. J Anim Sci 1997, 75:1415-1424.

27. Brake DW, Titgemeyer EC, Jones ML, Anderson DE: Effect of nitrogen supplementation on urea kinetics and microbial use of recycled urea in steers consuming corn-based diets. J Anim Sci 2010, 88:2729-2740.

28. Chumpawadee $S$, Sommart K, Vongpralub T, Pattarajinda V: Effects of synchronizing the rate of dietary energy and nitrogen release on ruminal fermentation, microbial protein synthesis, blood urea nitrogen and nutrient digestibility in beef cattle. Asian-Australasian J Anim Sci 2006, 19:181-188.

29. Seo JK, Yang JY, Kim HJ, Upadhaya SD, Cho WM, Ha JK: Effects of synchronization of carbohydrate and protein supply on ruminal fermentation, nitrogen metabolism and microbial protein synthesis in Holstein steers. Asian-Aust J Anim Sci 2010, 23:1455-1461.

30. Satter LD, Roffler RE: Nitrogen requirements and utilization in dairy cattle. J Dairy Sci 1975, 58:1219-1237.

31. Hammond AC: Effect of dietary protein level, ruminal protein solubility and time after feeding on plasma urea nitrogen and the relationship of plasma urea nitrogen to other ruminal and plasma parameters. J Anim Sci 1983, 57(1):435.

32. Hennessy DW, Nolan JV: Nitrogen kinetics in cattle fed a mature subtropical grass hay with and without protein meal supplementation. Aust J Agric Res 1988, 39:1135-1150.

33. Tedeschi LO, Baker MJ, Ketchen DJ, Fox DG: Performance of growing and finishing cattle supplemented with a slow-release urea product and urea. Can J Anim Sci 2002, 82:567-573.

\section{doi:10.1186/2055-0391-56-14}

Cite this article as: May et al:: Influence of ruminal degradable intake protein restriction on characteristics of digestion and growth performance of feedlot cattle during the late finishing phase. Journal of Animal Science and Technology 2014 56:14. 